\title{
LEARNING AND SENSE: BAKING ACTIVITY OF SETTLED WOMEN
}

\author{
MARCIA V. PAIXÃO ${ }^{1}$ \\ (iD) https://orcid.org/0000-0003-2889-6489 \\ ELOY E. S. NOGUEIRA ${ }^{2}$ \\ (iD) https://orcid.org/0000-0002-5234-496X
}

To cite this paper: Paixão, M. V., \& Nogueira, E. E. S. (2019). Learning and sense: Baking activity of settled women. Revista de Administração Mackenzie, 20(2). doi:10.1590/1678-6971/eRAMG190053

Submission: Apr. 18, 2018. Acceptance: Aug. 30, 2018.

1 Instituto Federal do Paraná (IFPR), Curitiba, PR, Brazil.
2 Universidade Positivo (UP), Curitiba, PR, Brazil.

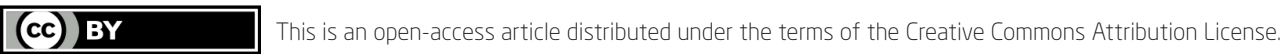

This paper may be copied, distributed, displayed, transmitted or adapted if provided, in a clear and explicit way, the name of the journal, the edition, the year and the pages on which the paper was originally published, but not suggesting that RAM endorses paper reuse. This licensing term should be made explicit in cases of reuse or distribution to third parties. It is not allowed the use for commercial purposes.

Este artigo pode ser copiado, distribuído, exibido, transmitido ou adaptado desde que citados, de forma clara e explícita, o nome da revista, a edição, o ano e as páginas nas quais o artigo foi publicado originalmente, mas sem sugerir que a RAM endosse a reutilização do artigo. Esse termo de licenciamento deve ser explicitado para os casos de reutilização ou distribuição para terceiros. Não é permitido o uso para fins comerciais. 


\section{ABSTRACT}

Purpose: This article is the result of an ethnographic study carried out in a settlement in the interior of Paraná, Brazil, which, from the perspective of the Social Learning Theory, aimed to understand how the learning of the productive baking activity of settled women occurs, serving as a path to a diversity of studies that seek to understand why certain practices emerge, institutionalize or are altered over time through an approach that sees them as a collective endeavor.

Originality/value: In revealing the sense of the activity and participation of these women in the baking activity and their relation with learning in the enterprise, this study was justified for its contribution to the understanding of this learning, answering questions that can serve as reference to understand the reality of productive groups of this new economy.

Design/methodology/approach: The proposals of Engeström (2009) and Nicolini (2009) formed a methodological package whose results showed the sense of activity as the search for an identity, the will to belong, factors generators of internal and external contradictions that extend the horizon of possibilities of the enterprise, leading to an expansionary cycle that causes the development of learning.

Findings: The results revealed that in the system of activity, learning and participation are intrinsically related, associating the development of the group with participatory learning and the negotiation of meanings in the community in which it is inserted, linking past and future, individual and collective, new and existing knowledge, in a transformative movement of identities of the subjects and generator of a socially constructed knowledge.

\section{KEYWORDS}

Learning. Sense. Identity. Activity. Participation. 


\section{INTRODUCTION}

In the late 1960s, Brazil saw the birth of collective social movements because of the increase in poverty and underemployment associated mainly with the agrarian structure, concentrated in large estates, and the type of employment and income generation produced by the capitalist society. As an alternative, forms of organization such as associations, productive groups and cooperatives began to be inserted in the productive market in a movement called Solidary Economy (Singer, 2000).

According to Gaiger (2006), the mutually advantageous relationship between solidarism and economic entrepreneurship in these enterprises is compromised by the need for a minimally qualified workforce, demanding the transfer of professional knowledge to the members of the group. Thus, the pressure for efficacy ends up pushing these subjects towards the need for seeking alternatives, for learning, demanding from them a condition of will (Laville \& Gaiger, 2009).

In the last years, the conjunctural changes and attempts of structural changes have produced transformations that can mean the destabilization of employment (Antunes, 2012). Employment, here, is taken in its ontological sense as a human activity vital for the formation of men, because it enables their relation with nature and with other men originating what is called humanity (Marx, 1996; Vygotsky, 1995). This justifies the increased relevance of these other economic models of production and employment, as well as the studies that seek to understand not only their genesis and effectiveness, but also the emersion of the subjects in conditions that make them effective, to face and change the socioeconomic reality.

These enterprises propose an organizational arrangement that allows alternatives to generate employment, production and income, and whose principles are anchored on free adhesion, cooperation, self-management, common good and collective action (Cole \& Engeström, 1997), converting experiences into communities of practices and inserting a new protagonist in the world of employment.

One of these protagonists is the landless rural workers born of the Agrarian Reform that have already settled, in Paraná alone, 18,000 families by transferring the possession of unproductive lands, and by the struggles organized by the Movimento dos Trabalhadores Rurais Sem-Terra (Landless Rural Workers' Movement - MST). Among these settlements is the Oito de Junho located $8 \mathrm{~km}$ from the city of Laranjeiras do Sul, in the western region of Paraná, legally established in 2000 from the expropriation by INCRA of 
an unproductive farm of 1,477 hectares. There are 71 settled families of the agrarian reform living in the locality from the productive activities of milk, agriculture and bakery (Paixão, 2014), and in a little more than 10 years, the Settlement, which produced an association of agroecological producers and a women's association, evolved into the creation of an agro-industrial cooperative - Coperjunho.

Over time, someone designs a project when they face a situation. It stops being a dream and it becomes an element shared by several people. And this sharing becomes an action, driving itself towards the realization of the enterprise that undergoes different phases. The first phase, or the phase of ignorance, is the domain of the conditions for the creation of the enterprise, and it demands something - a determination, a will — that over time keeps people together while the enterprise is not yet constituted. This determination for the realization of something, from Vygotsky's point of view (1995), is the will, which is historically constructed and developed in the relationship between the subject and the other person.

While people do not have machines, equipment, raw material, profit, while there are doubts, choices and mistakes and there is still no convincing that the project is good, during all this time, something keeps the group aware of the learning related to this enterprise, because, even though each one desires the individuality, "this desire exists only because the individual lives in a symbolic world shared with the desire of the other and it will only become real because it is also real to the other person" (Vygotsky, 1995, p. 301).

The relationships of interdependence, of interaction, will characterize the activity system by the permanent negotiation of meanings between the subjects interacting in the activity and with the context. The understanding of the context in which human activity takes place requires an understanding of the elements of time, space, place and sequence of events that, considering all the relations of meaning established between participants of the activity and those elements that form the context, makes it possible to reveal fundamental aspects of the subjects' conceptions of the activity. This means that analysing elements of this context separately, making cuts in reality, makes it impossible to understand the phenomenon.

Leontiev (1978) understood the context as an element of the dialectical synthesis between the senses (personal and specific of the subjects in the activity), and the meanings (collective and stable in the culture). This dialectical relationship produces the negotiation of meanings between the interacting subjects, giving rise to new meanings for the activity. Thus, changes in context may alter the meanings and motives of the activity. 
In this way, the women group's activities have a sense and a meaning private and collective - within the context where they occur, have a history and are guided by a larger system that guides the norms of the group's practices. It is not possible, then, to study the baking activity system on its own without considering the elements of the context.

Its existence demands survival, the ability to solve problems and to rebuild itself in the dialectic of the plural and the singular, past and present. Hence the presupposition of this research is that learning describes the involvement of the subject and the object in a trajectory of existence of the set of activities whose essence is employment, where men make use of instruments as a means for the transformation of nature and himself (Leontiev, 1984).

Understanding how this group learns, how knowledge is generated to create the activity, what mobilizes people, the context of the activity, are elements that cause us to question, first of all, why they participate in this activity. Thus, understanding the sense of the activity for the subjects and their participation can help us answer how the group learns to undertake, and vice versa, showing the relevance of the study to other productive groups of the Solidary Economy.

Engeström, Puonti, and Seppânen (2003) will affirm that the Theory of the Activity helps research, from the perspective of the Social Learning Theory, to answer questions such as the nature of collective learning. We hope that these reflections can help us understand the reality of productive groups in this new economy and, also, to understand how they are increasingly learning and conquering subjects of their actions and undertakings.

Thus, this study, when seeking to reveal the meaning of activity and participation in the baking activity of these women and what their relationship with learning in the enterprise is, is justified by its contribution to the understanding of this learning, answering questions that can serve as reference to understand the reality of productive groups of this new economy.

\section{THEORETICAL FRAMEWORK}

The present studies on learning are based on concepts of learning processes, but that have been criticized by several authors as stated by Vayda et al. (1991) because they embrace a theoretical definition that is not appropriate and often unreflective and comprises a process as a sequence of 
actions independent of human action, eliminating any substantive and reflexive conceptualization of the process, which become prescriptive approaches. These theories have been replaced by approaches that capture the essence of learning through the lens of perspectives such as those of Lave and Wenger (1991), Jonassen (2000), who abandon the learning process term and go in search of theoretical contributions of scholars such as Lev S. Vygotsky to understand the learning phenomenon, adopting the premise that learning is not restricted to the subject's mind, but to processes of participation and interaction and that for its understanding, it is necessary to understand the social interactions of activities the confirm the learning (Engeström \& Sannino, 2012).

One of these theories is the Cultural Historical Activity Theory (CHAT), where studies were developed on the human activity initiated by Leontiev, with Galperin (1957) as the first student to contribute with theoretical and methodological content to the learning theory based on the concepts of mediation and internalization of Vygotsky. His ideas had great repercussion in Russian psychology and paved the way for others such as Elkonin and Davydov from the 60s to the 80s (Werstch, 2011).

For Elkonin (1987), learning leads to development through the activity. His theory took into account external factors such as the incorporation of culture that would have a historical formation, not previous data. It was precisely this aspect that Davydov incorporated into his studies formulating a theory of learning based on Vygotsky, Leontiev and Elkonin, in which culture, meanings, language, relationships and interactions, mediation and the sociocultural context gained relevance for learning (Davydov, 1978).

But Davydov's theory was built to transform the classroom. With the expansion of CHAT from the 1980s on, names like Michael Cole emerge in the United States as one of Vygotsky's scholars. Congresses on the Theory of Activity are organized in Europe: ISCAR (International Society for Cultural and Activity Research) was founded in 1986, and in 1994, at the University of Helsinki, Finland, the Center for the Activity Theory and Research of Development Work was founded by Yrjo Engeström.

Yrjo Engeström develops his studies by giving them the name of Expansive Learning Theory (ELT), arguing that human beings and their collectives, regardless of age, are creators of a new culture and learn through expansion (Engeström, 1987). It focuses on the learning processes in which the subject of learning per se is transformed from a system of collective activity or from a network of activity systems. By questioning the existing order and logic of their activity, in a collaborative analysis, they give rise to 
the formation of a new object and a new pattern of activity, in a developmental logic based on the resolution of their internal contradictions. In expansive learning, a simple initial idea is transformed into a complex object, into a new form of practice (Engeström \& Sannino, 2012).

At this point, we see the justification for choosing this approach for the study of learning in the productive group. Based on the dialectics of the rise from the abstract to the concrete, ELT can provide us with a structure to analyse the interaction between the object under construction, the mediating artifacts, and the different perspectives of the participants in a progression of actions that have been and are being carried out collectively (Engeström, 2008).

In addition, ELT deals with an element of fundamental contribution to the understanding of learning in the productive group and which Engeström would call expansive transformation. The history of the enterprise left a strong mark on the development of its practices in order to reach a horizon of possibilities that the group saw and that was greater than the previous mode of the activity. This development is often conflicted by new motives, and so on several occasions the system of activity, undergoing practices, standards, rules, production relations, division of the work and voices of different players, are continually re-conceptualized, characterizing a spiral cycle, which ELT would call the expansive learning cycle (Engeström \& Sannino, 2012). This paradigm of praxis will broaden the studies of Vygotsky and Leontiev by allowing the understanding of the coexistence and interaction of various systems of activities or cultures, which is also very clear in the bakery system studied that is strongly guided by another system of activity also located within the settlement, that of the cooperative.

\section{METHODOLOGY}

This study was concerned with a research methodology that was compatible with the ontological and epistemological assumptions of the Expansive Learning Theory, giving voice to a man who is concrete and social. For this, the ethnographic perspective enabled the study of particular aspects of everyday life, in which the learning aspect implies in the revelation and interpretation of social practices from the situation in which they occur. The assumption is that knowledge of the social world can be generated by observation and participation in interactive situations in the context in which the phenomenon occurs. The researcher observes and participates 
dialectically and produces, along with the subjects under study, the meanings of the events.

Valuing the context of the subjects through their understanding of it, focusing on the specific as an instance of social totality, we understand learning as a product of the activity; for this reason, we took it as a unit of analysis. Individual actions were interpreted in the socio-historical context in which they are carried out, since human practices are socially constructed and situated and are given by the mediated participation in socio-cultural activities (Vygotsky, 1995). Interaction provides an interpretative basis from which individuals attribute meaning to their own actions and those of others (Wertsch, 1985). In this way, we used anthropological methods, a methodological design arising from the combination of the needs to understand in depth the place in which the practice itself takes place (Engeström's Activity System Model), following the players through focused ethnography and historical research, whose possibility of interpretation we found in the interpretative analysis. Aiming to understand and validate the meanings attributed by the subjects to their socio-cultural context, from the description, analysis and interpretation, the research counted on the immersion of one of the researchers from December 9, 2013, to January 31, 2014 , in the natural environment of the subjects to see, observe, listen and record the data collected through participant observation techniques, observational participation, field diary, visual records through photos, document analysis and interviews with the group of forty women belonging to the sector, whose benefit were narratives from life stories, believing that, being the act of remembering an act of giving social meaning to the experiences and individual feelings of the past, individuals end up making their experiences responsible for their current social context (Engeström et al., 2003) and that this helped us identify the activity system proposed by Engeström (1987).

In addition, specific aspects suggested by Nicolini (2009) were incorporated, that seek to identify 1 . the actual doing and its temporal flow, 2. the interaction patterns performed by the practice, 3 . the horizon of sense and the concern in which the practice unfolds and 4 . the active contribution of the artefacts and other practices in the accomplishment of the activity in question. This search led to the adoption of a recursive movement of zooming in and zooming out, promoting a convincing and meaningful description of what the practice is, why it is the way it is and why it is not done differently, guiding the researcher's gaze through questions a priori. 


\section{(Figure 3.1)}

GUIDING QUESTIONS OF THE RESEARCHER'S LOOK

\begin{tabular}{|c|c|c|}
\hline $\begin{array}{l}\text { Activity system } \\
\text { (Engeström) }\end{array}$ & Zoom in (Nicolini) & Zoom out (Nicolini) \\
\hline $\begin{array}{l}\text { Who are the subjects of } \\
\text { learning? }\end{array}$ & $\begin{array}{l}\text { The actual doing and its } \\
\text { temporal flow. }\end{array}$ & $\begin{array}{l}\text { The intermediaries of the } \\
\text { practice. }\end{array}$ \\
\hline Why do they learn? & The patterns of interactions & \multirow{3}{*}{$\begin{array}{l}\text { The relationships through which } \\
\text { practices are woven and the } \\
\text { effects that produce their } \\
\text { connections in the world. }\end{array}$} \\
\hline What do they learn? & carried out by the practice. & \\
\hline How do they learn? & $\begin{array}{l}\text { The horizon of sense in which } \\
\text { the practice unfolds. }\end{array}$ & \\
\hline Multivoicedness & \multirow{4}{*}{$\begin{array}{l}\text { The active contribution of the } \\
\text { artifacts and other practices in } \\
\text { the accomplishment of the } \\
\text { activity. }\end{array}$} & \multirow{4}{*}{$\begin{array}{l}\text { How different practices are } \\
\text { carried out in different places } \\
\text { and under different conditions. }\end{array}$} \\
\hline Historicity & & \\
\hline Contradictions & & \\
\hline Expansive cycle & & \\
\hline
\end{tabular}

Source: Elaborated by the authors based on Engeström (1987) and Nicolini (2009).

\section{RESULTS AND DISCUSSION}

Engeström's model shows an object that moves from an initial state to become a collective object, significantly constructed and shared. And it is precisely this process of transformation from the individual to the social that occurs in a network of systems of activity full of conflicts that the author seeks to understand. For him these conflicts are what motivate change and development (Engeström, 1987).

These collective systems of activities comprise the relation between objects in constant movement, which are mediated by artefacts and oriented to the object, and are related to other systems of activity. This concept led Engeström (2004) to state that an activity system can be perceived empirically from five essential factors. For an in-depth understanding of the place of execution of the practice, we begin with the principle of historicity, where we have the baking industry as a system of activity mediated by material and cultural artefacts that apply to the system a collective and solidary character.

In 1997, four women from the settlement gathered to produce bread to be sold in the city. With the growth in demand, in 2004 the women's association was formed, which already had 18 members. At that time, the first expansion of the kitchen took place. In 2006, the association enrolled its first project in the Food Acquisition Program and began to receive funds 
from the National Supply Company, strengthening the group. In 2007, the Agroindustrial Cooperative Oito de Junho was established with 35 women. That year, they won the bid of the university canteen that led to the new expansion.

The actions of the activity system are the production of baked goods and crumb cakes for school meals, savoury products, cookies, biscuits, cakes, sweets, control of school lunch projects, packaging and labelling, coordination of the production and quality of the products, management of the administrative department and marketing.

In this way, the baking activity system ends up being constituted by several sub-activities that are performed through actions driven by daily goals and are performed by various women involved in the activity. Its result meets the needs of the group and of the individuals.

(Figure 4.1)

PARTIAL DESCRIPTION OF THE BAKERY ACTIVITY IN LEVELS

\begin{tabular}{lll}
\hline \multicolumn{1}{c}{ Activity system } & \multicolumn{1}{c}{ Actions } & \multicolumn{1}{c}{ Operations } \\
\hline \multirow{3}{*}{ Bakery productions } & Plan & Beat the batter \\
\cline { 2 - 3 } & Coordinate & Cylinder \\
\cline { 2 - 3 } & Store & Open the batter \\
\cline { 2 - 3 } & Create recipes & Stuff \\
\cline { 2 - 3 } & Pack and label & Bake \\
\cline { 2 - 2 } & Market & Clean \\
\hline
\end{tabular}

Source: Elaborated by the authors.

The women's actions and operations transform the object into result (the reason for the activity) through material mediation artefacts - tools, instruments, machines - and symbolic — signs, language - that are used to manipulate and understand the object. This object has social consequences, so it is mediated by rules and norms that mediate the relation of these women with the community and this will relate to the object through the division of the work.

This community comprises many people interested in the activity. Besides the women, the group's results are of great interest to the settlement, the cooperative, customers and partners. Thus, the different individual actions, strongly included in a collective context, are driven by social rules 
established within the group and the community. These are rules such as banning the use of cell phones, working hours, following the recipe approved by the group, for example, and still not to abandon activity in their batches. Women should also attend the women's school where training is given on citizenship, gender, values of movement and the group itself.

The division of tasks, shifts, and the form of organization are discussed in a meeting and, when there is a need for greater knowledge on the actions, trainings are elaborated in order to optimize the process of transformation of the object in the expected result. From the point of view of the Activity Theory, the activity object of the bakery group seems to be associated to the process of production of baked goods and other products to be marketed in the community in which the settlement is inserted.

\section{(Figure 4.2)}

\section{INTERCONNECTION OF ACTIVITY SYSTEMS (A.S.)}

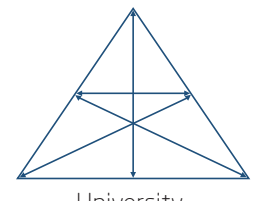

University

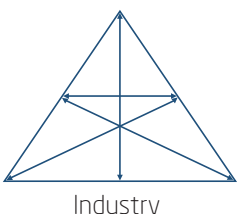

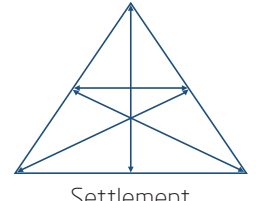

Settlement
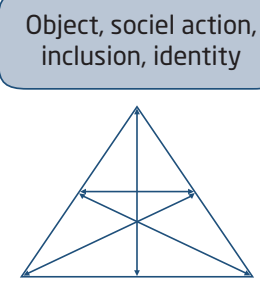

MST

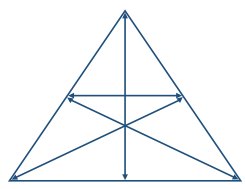

Government

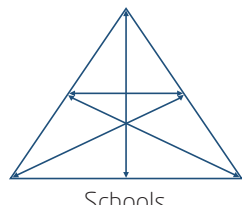

Schools

Source: Elaborated by the authors.

Due to the growth the group has been presenting, some women move once a week to other camps and settlements to take their experiences to other productive groups. But they do not just take knowledge about bakery. In these meetings, they talk about the values of the movement, the role of women and men in the family, and the income and exercise of citizenship. Most of the women have not completed the elementary education, but they pass on to other groups notions of management, of quality, and of productive organization. They provide ideas of inter-cooperation and present forms of partnerships that can be established. New products are debated and tested 
by them. Collaboration is a constant and the goal is common: delivering daily production (Paixão, 2014).

In relation to the hierarchical levels of activity, we have at the level of activity - bakery production - at the level of actions - to plan the production, coordinate, store, label, pack, and create recipes - and at the level of operations - mix the dough, rolling, opening the dough, stuffing, baking, cleaning, etc. - a series of routines, subordinated to goals and oriented to a collective motive. These routines are known by everything that they pass on to the others, the guidelines necessary for the execution of the operations.

They learn to live with more quality of life, to be more independent, to coordinate the efforts of people, to understand their status as a working woman, to communicate better, among many other things that we saw. They have a higher self-esteem, more vanity and are more confident than women from other settlements. It is a situated learning. These women act in the world and deliver various forms of production. They present a learning process that occurs as they change their form of participation, becoming socially engaged not only in their activity system, but in other systems. Lave and Wenger (1991) call situated learning the process where the beginner acquires knowledge, behaviors and beliefs of the community of practice as they participate more and more in the community. But in the productive group, this situated learning expands to other communities. The more women participate in other activity systems, the greater the learning that is shared with other activity systems. All of the women in the group participate in other activity systems. And we are not only talking about the work in their batches, but about their active participation in the women's school, the workers' movement, the cooperative's decisions, the improvements to the settlement, the meetings with other groups and the training and qualifications. A participation that cannot be described just as to how they participate, but that must question why they participate. This is because it was made clear in the observations that these women wish, as well as better living conditions for themselves, the same for other women who live under the same conditions. As common speech among them we could probably hear them say that, "today I know more about the world and I want others to know this" (Paixão, 2014). 


\section{(Figure 4.3)}

\section{DESCRIPTIVE PRINCIPLES OF THE EXPANSIVE LEARNING AND THE CONSTRUCTION OF THE WILL MOTIVE}
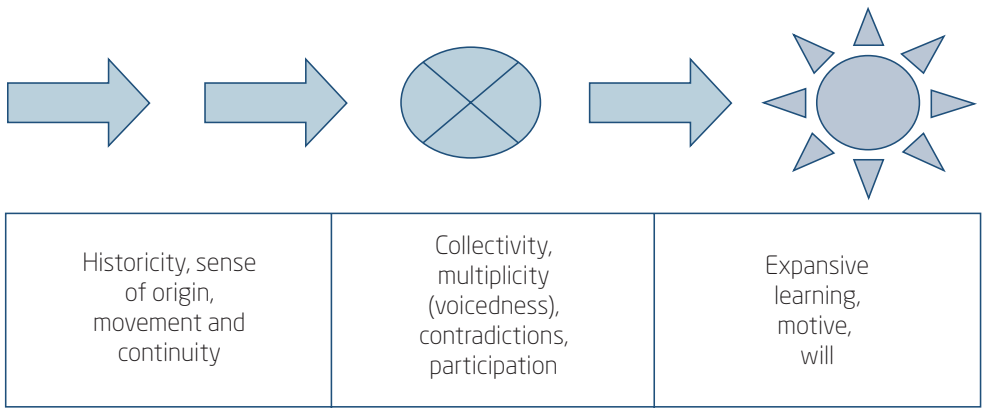

Source: Elaborated by the authors.

The principle of historicity seeks to understand which elements allowed the structuring of the activity system and how its creation process took place. When analysing women's speeches, two themes were recurrent: will and motive. A historically constructed will was developed in the relationship of the subject with the other and that kept the group's awareness attentive to the learning related to the enterprise. For Vygotsky (1995, p. 301), any realization is born from a function of the will. This will exists only because men live in a world shared with the desires of others: "The individual limit is the will of the other and is inscribed in this symbolic world that only becomes reality because it is also reality for the other". In this way, the will in Vygotsky is a way of thinking and is culturally constructed.

But that mobilizing will that kept the group's determination emerged from a motive. This motive is strongly related to the values that the group carries, the set of social activity that, according to Leontiev (1978), is what gives meaning to individual action. For him, there can be no activity without motive, the motive that impels the subject to participate in the activity with his individual action.

The collective discourse showed the union of people as a reason to allow not only the construction of better living conditions for active subjects of their own businesses, but also for their social inclusion, a strong characteristic of solidary economic enterprises. It showed people who wanted and want to demystify an image given to them by society can do it by participating in a situated activity that guarantees them an identity.

The second principle is the collective that seeks to find other results that could be shared by the activity system. Because the lands are small, the 
peasants cannot make the necessary living for their families from them, which means that almost everyone has jobs besides agriculture and livestock. Most of the men work in the tannery of the region or in the cooperative, besides the production of the batches. The women are distributed among the baking industry, in domestic services and in other commercial establishments.

The bakery activity system mediated by material and cultural artefacts is oriented to an object that is full of symbolism. Their results can be classified into three major outcomes: production, income and identity. We see here a collective that corroborates Engeström's (2004) statements that activity, in the process of its historical construction, contributes to the construction of the subjects' thoughts and identities, where meanings are negotiated in the context of mutual recognition and relationships are constructed through participation and make it possible to display the group's individual and collective identity. Participation as an active process and source of identity (Wenger, 2001).

From the point of view of the third principle, of Voicedness or multiple voices, an activity system is a community of multiple points of view, of traditions and interests, of situated individuals who carry their stories into a system where the division of work assigns them different positions and forms of participation. The division of work in the baking industry has shown the multiple layers and aspects of recorded history in its artefacts, rules and conventions. There are no bosses. Meetings are held for scheduling, shifts and assignments. Every morning women are given a list of what is to be produced.

Due to the difficulties with the control of production, the group decided to coordinate the process from the beginning to the packaging. Since none of the women had management training, they sought support from the president of the cooperative, who assumed the role of manager of the productive group.

The average age of the women who started the group today is 50 . With retirement just around the corner, they began a work of succession. But the division between these girls is very clear: a part of them work to supplement their income, study and pursue a career that is different from that of their mothers or that are there just to help at home intending to spend more time on farming. Their tasks are focused on production.

This multi-voicedness applies to the activity system a multiplicity of perspectives and interests of the system's community. The narratives show that the stories of different women carry different extracts of memory. The 
younger ones remember the camp as a good time, of friends, and of affection. The older ones remember the suffering.

In order to understand the fourth principle, the role of contradictions as sources of change, the local history has proved not to be sufficient to understand the system. Many contradictions have been brought about by elements present in the enlarged community, which we call challenges, which are the contradictions are tensions generated in and between the activity systems. By adopting a new external element such as a new technology, it will collide with some internal elements. With increased production, for example, to serve more schools in school meal programs, women had to promote efforts to create solutions that would adapt the system to meet the new demand. This provoked both the change and the development of the system that found the best way of resolving the conflict, by creating another shift. These contradictions respond to the fifth principle, presenting itself as questions about the activity and leading it to an expansive transformation, altering the concept of the object. In other words, an activity as a learning space that transforms the object by solving the contradictions that emerge within the activity.

The activity system shows that the new women, through interaction with the more experienced, acquire tacit knowledge of the industry and methods through demonstration. The older ones show newcomers the way things are done and then monitor them. Through participation, the younger ones listen to those who have more experience in the process and, over time, they assume more responsibility for what Lave and Wenger (1991) claim to be their own learning and participation in a collective activity. They also receive formation that initiates them in the history, the values, the beliefs and the organization of the group. This formation is given by the women of the group, where the older women talk about the trajectory of the enterprise and about the importance of the principles of the movement, such as cooperation and solidarity.

The learning process is most strongly supported by experimentation and informal meetings, but women do not deny the need for specialized knowledge. To improve the activity, the group seeks new technologies and information in the external environment, through a network of relationships with the aforementioned communities, in a coalition of diversified players. This network of partners is incorporated into the social context of the group and it occurs due to the strong political involvement of the individuals, strengthening the construction of processes of reflection and exploration of new concepts due to the generation of conflicts, seen as factors for need of change. 
To understand the movement of Zooming in, Nicolini (2009) proposes the identification of the current doing and its temporal flow, the patterns of interactions carried out by the practice, the horizon of meaning in which the practice unfolds (the horizon within which all discursive actions and material becomes possible and acquire meaning) and of the active contribution of the artefacts and other practices in the accomplishment of the activity. But looking at the accomplishment of a practice in a solidary enterprise requiresthe understanding of what to do, what must be done, and of the strong values orientation that the group possesses.

This identification revealed that the awareness of time in the women is not linear, even because we know that it is not possible for human beings to remember everything. Their memories produce a present and project a future. Older women seek to preserve the identity of the group in an effort to build a historical time in which their existence has and makes sense. This sense attributed to the group's historical memory is essential for individual and collective identity. The social space in which the various agents are organized, the individual and collective memory and the time form a historical culture that will constitute the identity of the group.

The experience of living with others around the group has created patterns of interactions that result in products that determine or limit women's actions. These products are not the baked goods, they are the traditions and the symbols resulting from the interactions with the MST. From the narratives, the presence of the values of the agrarian reform in the group became clear, as well as the principles of the movement.

Another product is the rules that must be fulfilled in order to meet the demands of the bids, production contracts, health surveillance and also values that must be followed by the enterprise to meet the cooperative model of management. The settlement has a core family base responsible for management, economic and social organization. This interaction ends up dictating behaviors that are incorporated into the group's culture. Thus, artefacts, norms, and values derive from the various interactions and are passed on to all women. 


\section{(Figure 4.4)}

\section{THE BAKERY ACTIVITY SYSTEM}

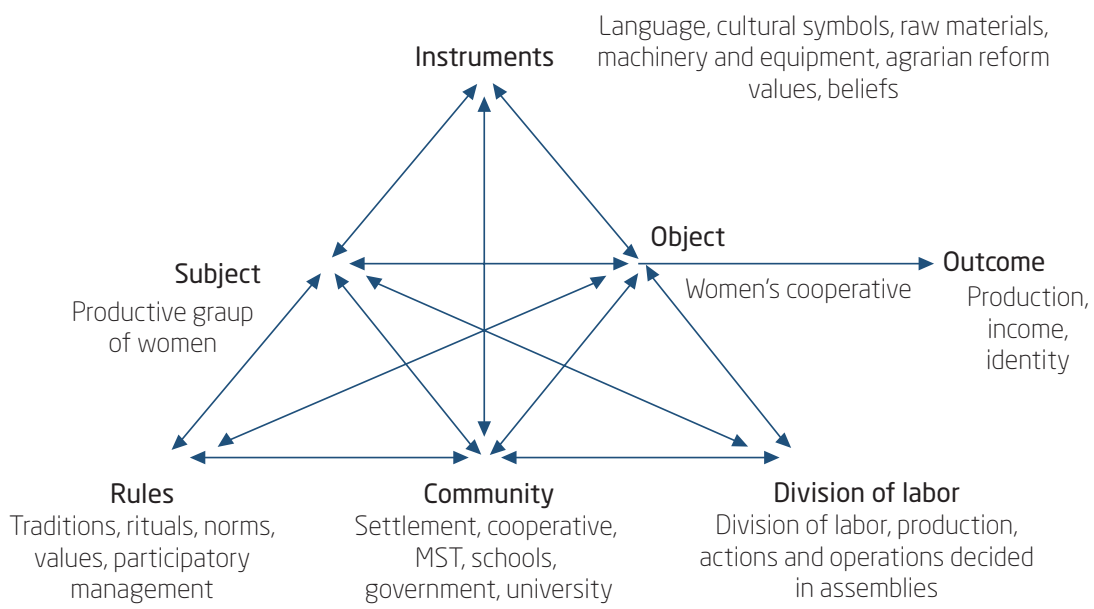

Source: Elaborated by the authors based on Engeström (2004).

The horizon of meaning in which the practice unfolds has led us to ask what makes them go beyond? What gives meaning to the activity of these women? What connects their actions to the purpose of the activity? Through the statements, it is possible to observe the concern in maintaining the current meaning of the activity. There is awareness that the industry's stage presents challenges to the group. To address these challenges, we found in the mediating artefacts the ways in which women are dealing with the contradictions that now challenge the current model of the industry.

In order to identify the active contribution of the artefacts and other practices in performing the activity, we take Wertsch's (1995, p. 64) assertion that every practice should be interpreted "as involving an irreducible tension between mediation instruments and the individuals employing these means". And we can see that the subjects do not act alone; their activity is mediated by material and symbolic tools that facilitate collective actions, transform them and bring about redefinitions of the cultural processes, knowledge and the individual. This was evidenced in the horizon of the sense of practice.

The reason of the activity starts a process of redefinition when the vision of the future of bakery presents contradictions that will take the activity to a new expansionary cycle. Although the beliefs and symbols currently present in the system are continuously reinforced in the group, the technologies have facilitated the productive process so that the younger ones no longer 
see the difficulties faced by the older ones at the beginning of the enterprise. These technologies range from new machines and equipment for the production of new products to the incorporation of new values.

The organized nature of interactions stems in part from the fact that both the women and the community are in line with the horizon of sense and in all the practical concerns that contribute to sustaining the activity. Being socialized in practice by formations and interactions, the women become part of a pattern of order and values that are inherent to the activity, appropriating the goals and rules.

But supported by Nicolini's (2009, p. 7) studies, we could not study the activity system without investigating the "connection paths between the practices and their products". Any practice is involved in a variety of relationships and associations that extend in space and time, and forms a great texture of dependencies and references, a rhizomatic model, as Nicolini (2013) states. The study of a practice cannot be limited to the details of its accomplishment. It also requires assessing how the activity site is affected by other practices and how these practices are affected by the activity under study, the consequences of these relationships and connections.

Thus, the study was extended from the original site to other sites that emerged as relevant to the understanding of the activity. We observed for an extended period the practice in the context of the daily routine of women in the bakery group. Meetings, celebrations, training sessions, political and social gatherings, other settlements, men from the community, industry clients have enabled us to research data for an in-depth understanding of the sites for the practice.

By the principle of Zooming out, we observed an activity system that is linked to others due to the results delivered. The results are absorbed by consumers, other productive groups, schools and the MST itself. It is linked to other practices outside the system that women participate in, which are their activities in the batches - planting, harvesting, and caring for the home and the children. They are linked to MST practices that take the group's experiences to other settlements where they merge with other practices in teaching other women. The results are also linked to the schools to which they deliver school meal products and the cities where they market their products.

As for other practices that affect or allow the activity, there is the production of the batches that provide inputs to the industry. Part of the production of the 74 batches of the settlement is absorbed by the group. Fruits, vegetables and milk are used in the production of sweets, tarts, 
meals, as well as other settlements. The cooperative assists women in the management of marketing activities, establishment of partnerships and search for new markets, in addition to the pricing of products and the preparation of projects to participate in bids. The MST offers to the women courses and training in agroecology, political awareness, gender and production methods. The core management of the settlement offers a space for discussion of future paths for the enterprise. Coming from rural worker families, these women have not lost their relationship with the land. Linked to the movement, a strong link is visible with the ideal of agrarian reform defence, the adoption of the agroecology flags and the production of healthy foods because of these other diverse activity systems in which they participate.

\section{FINAL CONSIDERATIONS}

While the individual vision dominated the studies on learning, a more collective perspective emerged based on the historical materialism of Marx and Engels: the Russian psychology of Vygotsky and Leontiev that formulated the Cultural Historical Activity Theory. The epistemological implications of this approach for the studies on learning are profound. Firstly, learning is situated and is the result of interactions among people in a collaborative activity. Second, because learning and meanings are constructed by the participants in a social practice and, through it, they develop an identity. And if learning is situated in practice, then practice precedes knowledge (Hedegaard, 2002).

Thus, sense arises from activity, directed and situated, and its subjective product is the consciousness which, according to Leontiev (1978) exists only from a social conscience. To find the sense of activity, it is necessary to discover its motive, following the object. And if the sense of the baking activity is determined, then, for the reason that women possess in the bakery system, the search for an identity will give meaning to the woman who produces, surpassing the logic of reproduction of capital, in an enterprise whose principles of solidarity and participation create a less utilitarian market.

There is strong group awareness in the baking industry. From the beginning, they come together to share ideas, their desires, ways to improve, learn from each other and have a strong sense of belonging, because the enterprise is something that is theirs. The activities within the system are linked by a history and common interests, leading to the simultaneous 
occurrence of learning and practice, which Wenger (1998) called collective learning. They are women who share a common enterprise, with an economic logic different from the traditional one, and which, by values strongly supported in the collective, make up an identity that gives way to a repertoire of material and symbolic resources.

Regarding the sense of activity for these women, we assumed the identity as a response. Although the income is the motive that also moves them, the group continually uses material and symbolic artefacts to make them assume the values of the group, which are very present in the bakery, cooperative and settlement systems. They are celebrations, training sessions, and meetings where women constantly, through memory, try to instil in the younger ones the values of the group and of the movement.

Field research has shown that these women carry a will that mobilizes and makes them want their desires to be shared by everyone. A will, as Vygotsky (1995) has pointed out, is culturally constructed and maintains the determination of the group, whose motive is related to the search for identity, attributing meaning to the bakery activity. Thus, the motive that drives the subject to participate in the activity with their individual action is not only in the construction of better conditions of life, but in the possibility of their social inclusion, of knowing and acting in the world. Given this, the sense of women's participation in the activity appears as a search for social affiliation. Wenger and Snyder (2001) describe participation as the social experience of living in the world and participation in the activity, for these women, guarantees them mutual recognition and new forms of life.

And following the object of the bakery activity system, it was possible to perceive that object and motive are re-conceptualized to reach a wider horizon of possibilities, leading the activity to an expansive transformation, in order to respond to the impacts of the other activity systems that, together, have been composing the social context where the practice takes place. The reason, the sense of the activity and the participation of these women, materialized in the object - baking industry - becomes an outcome and both are absorbed by other systems. In understanding the multiple perspectives and networks of interactive systems, the objects of the activity systems, upon receiving the outcomes of the bakery system, claim the ideals of the agrarian reform. Because of the objective (motive) of each system, contradictions are the way of pushing systems to evolve in the quest to keep their objects alive, guiding subjects to act in the world. It is a network of interconnected activity systems that will combine their objects to generate a 
shared object that we call the ideal of the agrarian reform (Engeström \& Sannino, 2010).

Roth (2004) states that the object is the sum of the object of the practical activity and the object of thought. The object of the practical activity, the baking industry, produces as a result the production and the marketing of baked goods. But the object of thought is to be the largest women's cooperative within the settlements, and it was by looking at other sites by the Zoom Out movement (Nicolini, 2013) that it was possible to see that industry results are shared by other activity systems such as canteens, schools, the city, the settlement, the cooperative, the MST, that see the meaning of their objects.

But this is the object of the practical activity. As an object of thought, systems of activity reaffirm and share the ideals of the agrarian reform when everyone pushes the industry towards evolution so that their interests are optimized. Zoom Out made it possible to understand two things: first, that all practice is a weaving of words and actions, of places and objects that can also be objects of study. Second, it was possible to answer how the women of the Settlement managed to achieve what they did: by will. This study suggests the potential gains and innovations obtained by the adoption of the methodology proposed by Nicolini (2013) and Gherardi's (2009) critical reference for researching work and activity systems, describing their dynamics and interconnections and mediating elements.

The system of activity combines multiple interests and traditions of situated individuals who carry and seek to pass on their stories, filled with the memory of artefacts and symbols, into a system, generating tensions that lead women to change. These stories participate in the system as drivers of new ways of knowing, doing and being. The strong cooperative value eventually led them to want more and to share with other women what they had been conquering. This value was one of the sources of contradiction of the system. In an effort to grow and make room for other women, the baking industry eventually developed new forms of production.

In this context, in order to answer how the learning of the productive group of women occurs, the results revealed that in the activity system learning and participation are intrinsically related. Participation in the activity is configured as the learning principle that Daniels (2003) called "collaborative production". The development of the group is associated with participatory learning and to the negotiation of meanings in the community in which it is inserted.

Individual actions and operations reflect a dialogic process in which the exchange of experiences is gradually codified into new knowledge. Mutual 
dialogue and learning seem to be the key to the process, where joint analysis leads women to evolve over their actions, contributing to the accumulation of knowledge, to innovation within and beyond the system. The opportunity to participate actively is an important motivation for the activity.

We thus have learning based on theoretical and practical formation, but mainly on experience and social relationships, embodied in history that links past and future, individual and collective, new and existing knowledge, into a transforming movement of the identities of the subjects. Although they value the capacity to generate knowledge of external agents, the experiences and accumulated knowledge are given by the engagement in a collective activity strongly supported by the sharing of knowledge.

And the motive of these women boosted the activity, linking it with an object - the women's cooperative: "the object of the activity is its real motive" (Leontiev,1984, p. 83). They materialized their motives in the bakery activity and it was by looking at other places, guided by the questions of Nicolini (2013), through which we could understand how the women of the group achieved what they have achieved. As aforementioned, these women carry a will that mobilizes them and keeps them attentive to learning. With the growth of industry, this condition of will increased. The more women became part of the enterprise, the more people had access to the betterment of their lives, and more pressure there was on the industry.

Laville and Gaiger (2009) talk about this moment in enterprises of economic solidarity: the pressure for effectiveness in the activity demands a condition of will from their members, built strongly on values of solidarity and cooperation. In the industry, what drives them is not pressure for efficacy; it is a consequence. What drives them is the ideal, the desire for other women to achieve what they have achieved: to become agents in the world.

Finally, the objective of this research is to be used as a gateway to a diversity of studies that seek to understand why certain practices emerge, why they are institutionalized or why they are altered over time through an approach that sees them as a collective doing, where the objectives depend on the notion of unity and where learning and knowledge occur in practice and through participation. 


\section{APRENDIZAGEM E SENTIDO: ATIVIDADE DE PANIFICAÇÃO DE MULHERES ASSENTADAS}

) RESUMO

Objetivo: Este artigo é resultado de um estudo etnográfico realizado em um assentamento no interior do Paraná que, sob a perspectiva da Teoria Social da Aprendizagem, pretendeu compreender como ocorre a aprendizagem da atividade produtiva de panificação de mulheres assentadas, servindo como um caminho para uma diversidade de estudos que buscam entender por que certas práticas emergem, institucionalizam ou são alteradas ao longo do tempo por meio de uma abordagem que as vê como um empreendimento coletivo.

Originalidade/valor: Ao revelar o sentido da atividade e participação dessas mulheres na atividade de panificação e sua relação com a aprendizagem no empreendimento, este estudo foi justificado por sua contribuição para a compreensão desse aprendizado, respondendo a questões que possam servir de referência para compreender a realidade dos grupos produtivos dessa nova economia.

Design/metodologia/abordagem: As propostas de Engeström (2009) e Nicolini (2009) formaram um pacote metodológico cujos resultados mostraram o sentido da atividade como a busca de uma identidade e a vontade de pertencer, fatores geradores de contradições internas e externas que ampliam o horizonte de possibilidades do empreendimento, levando a um ciclo expansivo que provoca o desenvolvimento da aprendizagem.

Resultados: Os resultados revelaram que, no sistema de atividade, a aprendizagem e a participação estão intrinsecamente relacionadas, associando o desenvolvimento do grupo com a aprendizagem participativa e a negociação de significados na comunidade em que está inserido, ligando passado e futuro, individual e coletivo, conhecimento novo e existente, num movimento transformador de identidades dos sujeitos e gerador de um conhecimento socialmente construído.

\section{PALAVRAS-CHAVE}

Aprendizagem. Sentido. Identidade. Atividade. Participação. 


\section{REFERENCES}

Antunes, R. (2012). Adeus ao trabalho? Ensaios sobre as metamorfoses e a centralidade do mundo do trabalho. 14th ed. São Paulo, SP: Cortez Editora.

Cole, M., \& Engeström, Y. (1997). A cultural-historical approach to distributed cognition. In G. Salomon (Ed.), Distributed cognitions: Psychological and educational considerations (pp. 1-46). Cambridge, UK: Cambridge University Press.

Daniels, H. (2003). Vygotsky e a pedagogia. São Paulo, SP: Edições Loyola.

Davýdov, V. V. (1978). Tipos de generalización en la enseñanza. Havana, Cuba: Pueblo y educación.

Elkonin, D. (1987). Sobre el problema de la periodización del desarrollo psíquico en la infancia. In V. Davidov \& M. Shuare. (Org.), La psicología evolutiva y pedagógica en la URSS (pp. 125-142). Moscow, RU: Progresso.

Engeström, Y. (1987). Learning by expanding: An activity-theoretical approach to developmental research. Helsinki, FI: Orienta-Konsultit.

Engeström, Y. (2004). New forms of learning in co-configuration work. Journal of Workplace Learning, 16(1/2), 11-21.

Engeström, Y. (2008, Sept.). The future of activity theory: A rough draft. Lecture presented at the meeting of the International Society for Culturalhistorical Activity Research (Iscar), San Diego, CA.

Engeström, Y., \& Sannino, A. (2010). Studies of expansive learning: Foundations, findings, and future challenges. Educational Research Review, 5(1), 1-24. doi:10.1016/j.edurev.2009.12.002

Engeström, Y., \& Sannino, A. (2012). Whatever happened to process theories of learning? In Learning, Culture and Social Interaction (pp. 45-56). University of Helsinki, Finland, p. 45-56. doi:10.1016/j.lcsi.2012.03.002

Galperin, P. (1957). Sobre la formación de los conceptos y de las acciones mentales. Boletín de La Universidad Estatal de Moscú, n. 4.

Gherardi, S. (2009). Introduction: the critical power of the 'practice lens'. Management Learning, 40(2), 115-128. doi:10.1177/1350507608101225

Gherardi, S. (2003). To transfer is to transform the circulation of safety knowledge. In D. Nicolini, S. Gherardi, \& D. Yanow, Knowing in organizations. New York, NY: Sharpe. doi:10.1177/135050840072008

Hedegaard, M. (2002). A zona de desenvolvimento proximal como base para o ensino. In H. Daniels (Org.), Uma introdução a Vygotsky. São Paulo, SP: Edições Loyola. 
Jonassen, D. (2000). Critical thinking: The goal of mindtools. Computers as mindtools for schools: Engaging critical thinking. Prentice Hall.

Lave, J.; Wenger, E. (1991). Situated learning: Legitimate peripheral participation. Cambridge University Press.

Laville, J.-L., \& Gaiger, L. I. (2009). Economia solidária. In A. D. Cattani, J.-L. Laville, L. I. Gaiger, \& P. Hespanha, Dicionário internacional da outra economia. Portugal, PT: Almedina.

Leontiev, A. (1978). O homem e a cultura. In: A. Leontiev, O desenvolvimento do psiquismo. Lisboa, PT: Horizonte Universitário.

Leontiev, A. (1984). Activity conscience, personality. Moscou: Editions du Progr.

Marx, K. (1996). O capital: Crítica da economia política. S. Paulo, SP: Nova Cultural.

Nicolini, D. (2009). Zooming in and zooming out: A package of method and theory to study work practices. In S. Ybema, D. Yanow, H. Wels, F. H. Kamsteeg, Frans H. Organizational ethnography: Studying the complexity of everyday life. Thousando Oaks, CA: Sage.

Nicolini, D. (2013). Practice theory, work \& organization: An introduction. Oxford, UK: Oxford University Press.

Paixão, M. (2014). Sentido e participação na atividade de panificação das mulheres do empreendimento econômico solidário 8 de junho sob a ótica da Teoria Social da Aprendizagem (Doctoral dissertation). Universidade Positivo, Curitiba, PR.

Roth, W. (2004). Activity theory and education: An introduction. Mind, Culture and Activity, California, 11(1), 1-8.

Vayda, A. P.; Mccay, B. J., Eghenter, C. (1991). Concepts of process in social science explanations. Philosophy of the Social Sciences, 21(3), 318-331. doi:10.1177/004839319102100302

Vygotsky, L. S. (1978). Mind in society: The development of higher psychological processes. Cambridge, UK: Harvard University Press.

Vygotsky, L. S. (1985). Obras escogidas III. Madrid, ES: Visor.

Wenger, E. (1998). Communities of practice: Learning, meaning, and identity. Cambridge, UK: Harvard University Press.

Wenger, E. C.; Snyder, W. M. (2001). Comunidades de prática: A fronteira organizacional. In Harvard Business Review (Org.). Aprendizagem Organizacional. Rio de Janeiro, RJ: Campus.

Wertsch, J. V. (1985). Vygotsky and the social formation of mind. Cambridge, UK: Harvard University Press. 


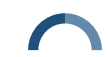

Marcia V. Paixão, Eloy E. S. Nogueira

\section{J Wrrtoen orors}

Marcia V. Paixão, Business School, Universidade Positivo (UP); Eloy E. S. Nogueira, Escola de Administração de Empresas de São Paulo (Eaesp), Fundação Getulio Vargas (FGV).

Marcia V. Paixão is now Master's Professor at Instituto Federal do Paraná (IFPR); Eloy E. S. Nogueira is now Researcher, Master's and Doctorate Professor at Universidade Positivo (UP).

Correspondence concerning this article should be addressed to Marcia V. Paixão, Avenida Senador Salgado Filho, 1200, Prado Velho, Curitiba, Paraná, Brazil, CEP: 80215-270.

E-mail: valeria.paixao@ifpr.edu.br

\section{EDITORIAL BOARD}

Editors-in-chief

Janette Brunstein

Silvio Popadiuk

Associated Editor

Andrea Rodrigues

Technical Support

Vitória Batista Santos Silva

\section{EDITORIAL PRODUCTION}

Publishing Coordination

Irina Migliari

Layout Designer

Emap

Copyeditor

Irina Migliari (English)

Graphic Designer

Libro
Language Editor

Daniel de Almeida Leão (English)

Irina Migliari (Portuguese) 